\title{
Developing Reading Worksheet for Tenth Grade Students of SMA Negeri 4 Palopo
}

\author{
${ }^{1}$ Lestari, 2 Dewi Furwana, ${ }^{3}$ Muhammad Iksan \\ 1,2,3State Islamic Institute (IAIN Palopo), Indonesia \\ dewifurwana@yahoo.com
}

\begin{abstract}
This research about Developing Students' Reading Worksheet of tenth grade at SMA Negeri 4 Palopo, the researcher formulated the research question as follow: what kind of Reading Worksheet are suitable for tenth students'. The objective of this research is to create and develop reading worksheets for tenth-grade students' by using the Addie design model. In this research and development from the Addie model, this consists of Analyzing, Designing, Implementation, and evaluating. There are 14 students and two experts'validation. The instrument of the data collection is a questioner. The result of the research shows that the researcher develops and make a product based on the students' need. And the development of this product is also carried out based on the syllabus and curriculum that apply in the school itself. Based on the worksheet, have a development already appropriate necessity and lack of the students, and with the development worksheet would students' reading ability.
\end{abstract}

Keyword: Developing, Reading, Worksheet.

\section{INTRODUCTION}

The use of students' worksheets or speak Bahasa LKS in teaching reading comprehension is importantly needed because it covers many kinds of exercises, reading, and activity. It will make students more active in learning reading. The use of worksheets in the teaching and learning process is really helpful for both teachers and students. Besides that, the worksheet created for a tenth grade should be based on the curriculum, which is implemented in SMA Negeri 4 Palopo. The base of observation the researcher found out the weakness of the study, including unsystematic and inappropriate reading learning media, which were taught by the study without considering the learner's need bases on their English competency levels (Enever, 2014). Hence in this study, the researcher focused on developing materials to make worksheet media. The researcher found many kinds of problems that we never found before, usually composed of how to solve them or what to do about them. In this case, students problem in doing the reading is that he does not know the language all enough or chunk effectively. Based on the problem statement above, the researcher formulates the research question as follows: "What kind of Reading worksheets is appropriate for tenth-grade students at SMAN 4 Palopo?" The objective of this research is to create and develop reading worksheet for the tenth-grade students by using the ADDIE design model (Wang \& Hsu, 2008)that the students become more accustomed to the exercises and types of reading this worksheet will drive the students to improve their comprehension in reading for tenth grade and the other side, to help the teacher to teach and as a reference into the teaching of SMA Negeri 4 Palopo.

\section{METHODS}

Procedures of Development

The research analyzed the syllabus used to gain information about the objective of the course and the materials needed by students. After analyzed the objective and material, research would consult them to the two experts and the lectures to decide whether the objective should be revised or not. The researcher also got information about students' compounds in reading ability 
from the observation. The research would researcher the objective of the course and selected the delivery materials. After that, research sequences the materials from the easiest to most difficult. Also, the researcher designed the selected materials in the form of worksheet and audio learning materials that appropriate and qualify learning materials (Iksan \& Dirham, 2018). It is for increasing students' skills in reading. The researchers develop and make a product according to need. Shortcoming of students', and the development of this product is also carried out based on syllabus and curricula that apply in the school itself. Before the researcher asks the teacher to use research, researchers in the researcher product in class validating by using small Forum Group Discussion (FGD) is the earlier action that research did. In other words, the worksheet would develop by applying this product to the students. The product to the tenth grade at SMA Negeri 4 Palopo and this step finally until the first and fourth steps. The researcher try-out the worksheet reading for students

\section{Design of the Material Try-Out}

Before making a worksheet for use in reading in the tenth grade, the researcher will interview and give the questionnaire to the students who become samples from each class. So, the researcher can know their need to increase their reading skill. After knowing students' needs, the researcher will design worksheets that suitable and appropriate for applying in their class. Then, the worksheet that already made by the researcher will be given to the teacher to use in the class for teaching the object of this study. This aims to get information (feedback) from the student about the worksheet. After the end of the class, the researcher will give the second questionnaire to the students and also the teacher for qualifying the worksheet that they used and also enactive the worksheet. Is that suitable or not. The population in this researcher is all students at tenth grade, SMA Negeri 4 of Palopo. And the sample of this researcher is one class (1 class). This research will be conducted at Agustus 2018 until the end of tenth grade SMA Negeri 4 Palopo. This research would be conducted at the SMA Negeri 4 of Palopo, South Sulawesi, especially for students oft tenth grade. The population in this research is all students IPS in tenth grade. The sample of this research is 14 students in each class. The research was conducted in Agustus $12^{\text {th }} 2018$.

\section{Procedure for Collecting Data}

The researcher would be given some questionnaires to the students, and collecting information about lacks, wants, and necessities from those questionnaires. The researcher would be observed the condition of students, the class, materials, and the level of the students. The researcher would be used documents and data records to the students and lesson plan, and syllabi.

\section{Data Analysis Technique}

Data technique analysis of this research used qualitative and descriptive because the data collected is qualitative data. The researcher gets the data from the questionnaires given to the students and also from the interview to some students and teachers, and it is for the qualitative data. The researcher would be trying to describe and give an explanation of the data taken from the questionnaires and worksheet validity.

\section{RESULTS}

Based on the questionnaire given to the teacher, the researcher get information about the problem in the student class $\mathrm{x}$ what is still need and the lack of students lies in the lack of vocabulary mastery, and from the data that researcher can see that students' prefer in Worksheet Reading. In this need analysis, the populations consist of 150 students, and the sample consists of of14 students of tenth grade. 
Tabel 4.1 Analyze the result of the questionnaire

\begin{tabular}{|c|c|c|c|c|c|c|}
\hline No & Questions & $\mathrm{A}$ & $B$ & $\mathrm{C}$ & $\mathrm{D}$ & $\mathrm{E}$ \\
\hline 1 & 1 & 10 & & 1 & 2 & 1 \\
\hline 2 & 2 & 4 & 3 & 6 & 2 & \\
\hline 3 & 3 & 7 & 2 & 1 & 4 & \\
\hline 4 & 4 & 6 & 3 & 4 & 1 & \\
\hline 5 & 5 & 7 & 3 & 4 & & \\
\hline 6 & 6 & 7 & 3 & 3 & 1 & \\
\hline 7 & 7 & 7 & 4 & 2 & 1 & \\
\hline 8 & 8 & 4 & 6 & & 4 & \\
\hline 9 & 9 & 3 & & 3 & 7 & 1 \\
\hline 10 & 10 & 4 & 6 & 4 & & \\
\hline 11 & 11 & 3 & 10 & & 1 & \\
\hline 12 & 12 & 2 & 2 & 3 & 5 & 2 \\
\hline \multicolumn{2}{|c|}{ Average } & 64 & 42 & 31 & 28 & 4 \\
\hline
\end{tabular}

\section{Result of the Question}

1. What is your current level of Reading mastery?

a. Basic (Lower): knowing a little vocabulary and limited grammar mastery.

b. Intermediate (Upper): although they still have difficulties in vocabulary and grammar, they can engage in Writing

c. Advance: able to read smoothly on most topics, and has only a few obstacles.

d. Intermedial (Lower): knowing a little vocabulary and limited grammar mastery.

e. Intermediate (Upper): although still has difficulties in vocabulary and grammar, but can engage in Writing

f. Advance: able to read smoothly on most topics, and has only a few obstacles.

g. Others (specify if any)

\section{Diagram 4.1}

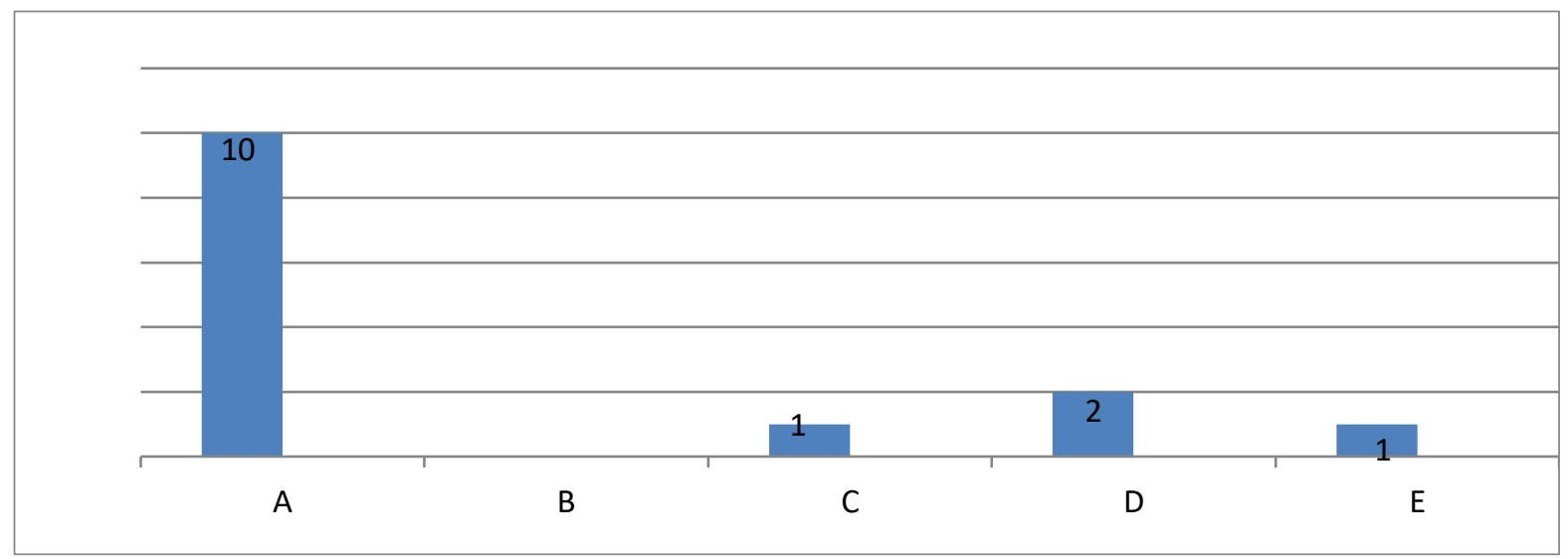

The percentage of the question shows that grade tenth level in Ips 2 is still in the Basic (Lower) level. It shows the percentage of students are choosing option $A=10$ students. It means that $85 \%$ of students are in the Basic (Lower) level. 


\section{The Course Grid}

According to the syllabus and curriculum in the school, and this school uses the $\mathrm{K} 13$ curriculum, from this syllabus and curriculum researcher made the material that was used by each school and the creation of this worksheet itself was inseparable from the data and information that had been obtaining from class $\mathrm{x}$ in the odd semester. The worksheet made consisted of two-unit, the first unit contains recount text and the second unit contains material about the descriptive text.

\section{Result of Expert Validation}

In this Expert Validation, the researcher validated the material by giving questionnaires to content and layout experts that contains questions about the product. There are 20 questions in the questions asking about all aspects of the product. Those aspects are content and layout, which were assessed by two experts. Below are the results from those three experts.

\section{a. Content Validation Lecture I}

\begin{tabular}{cccc}
\hline Question Number & Score & Question Number & Score \\
\hline 1 & 2 & 11 & 2 \\
2 & 2 & 12 & 3 \\
3 & 3 & 13 & 2 \\
4 & 3 & 14 & 2 \\
5 & 3 & 15 & 3 \\
6 & 3 & 16 & 2 \\
7 & 2 & 17 & 2 \\
8 & 3 & & \\
9 & 1 & & \\
10 & 2 & & 40 \\
\hline
\end{tabular}

Table 4.2

$$
\begin{aligned}
\text { Mean } & =\frac{40}{17} \\
& =2
\end{aligned}
$$

Based on the table above the content validation lecture I the researcher find the question number 1), the expert gave two scores, the question number 2), the expert gave two scores, the question number 3), the expert gave three scores, the question number 4), the expert gave three scores, the question number 5), the expert gave three scores, the question number 6 ) the expert gave three scores, the question number 7) the expert gave two scores, the question number 8) the expert gave three scores, the question number 9) the expert gave one score, the question number 10) the expert gave two scores, the question number 11) the expert gave two scores, the question number 12) the expert gave three scores, the question number 13) the expert gave two scores, the question number 14) the expert gave two scores, the question number 15) gave three scores, the question number 16) the expert gave two scores. The question number 17) the expert gave two scores.

\section{b. Content Validation Lecture II}

\begin{tabular}{cccc}
\hline Question Number & Score & Question Number & Score \\
\hline 1 & 4 & 11 & 4 \\
2 & 4 & 12 & 4 \\
3 & 4 & 13 & 4 \\
4 & 4 & 14 & 4 \\
5 & 4 & 15 & 4 \\
6 & 4 & 16 & 4
\end{tabular}


844

9

$$
\text { Mean }=\frac{68}{17}
$$

Table 4.3

Based on the table above the content validation lecture II the researcher found the in question number 1), the expert gave four scores, in question number 2), the expert gave four scores, the question number 3), the expert gave four scores, in question number 4), the expert gave four scores, in question number 5), the expert gave four scores, in question number 6 ), the expert gave four scores, in question number 7), the expert gave four scores, in question number 8), the expert gave four scores, in question number 9), the expert gave four scores, in question number 10), the expert gave four scores, the question number 11), the expert gave four scores, in question number 12), the expert gave four scores, in question number 13), the expert gave four scores, the question number 14), the expert gave four scores, the question number 15), the expert gave four scores, in question number 16), the expert gave four scores and in question number 17), the expert gave four scores.

From those two tables of experts' validity lecture I, the data show that the reading worksheet designed by the researcher is already qualified to apply in the class.

\section{Result Question for Students'}

Conducted to done interview with some student's, the researcher found that:

1. Some students like to work in pairs to finish the assignment, and some of them like to work individually to finish the assignment.

2. Most of the students are difficult to understand the reading because they are lack vocabulary, and they are difficult to find the main topic of the text.

3. This school does not have a worksheet to students

4. Some students like to read because they are think reading makes bored. Students need fun activities in these materials. But, some of them also think that reading comprehension materials can help them to increase their ability, especially in reading English.

\section{Result of the try-out worksheet}

After researcher try-out, the worksheet in some students, the researcher found that almost students say in terms of the material it's very good and perfect and some students say in terms of design had interested the students in teaching and reading, but one student would the researcher add the games into the worksheet. And conduct try-out the worksheet the students enthusiastic in done the worksheet and students very enjoy and according to the students the worksheet it's very easy. From this result, we could say that the worksheet already in accordance with what in need, desirable, and lack of students.

\section{DISCUSSION}

This research has covered all material and the indicator of material. This research can develop many fixtures of text, questions, and exercises. The researchers need to focus on each material. Arrange of the material needs need some revision to make students easier to understand reading comprehension. (Iksan \& Palangngan, 2018) The researcher used the long exercises will be difficult for students to understand. The researcher needs to give the vocabulary list in the read of reading text. It would be made students easy to understand the material. Add 
the vocabulary list also would increase the students' knowledge about the new vocabulary that they never read before.

The materials consist of two units. The topics are recount text, write text declarative, interrogative, and text descriptive. The researcher gets information about the problem in the student class $\mathrm{x}$ what is still need, and the lack of students lies in the lack of vocabulary mastery. From the data, that researcher can see that students prefer in Worksheet Reading. And this researcher had five steps: Analysis. The research analyzed the syllabus used to gain information about the objective of the course and the materials needed by students. After analyzed the objective and material, research consults them to the two experts and the lectures to decide whether the objective should be revised or not. The researcher also got information about students' competence in reading ability from the observation. Design the research designed the objective of the course and selected the delivery materials. After that, research sequences the materials from the easiest to most difficult. Also, the researcher designed the selected materials in the form of worksheet and audio learning materials that appropriate and qualify learning materials. It is for increasing students' skills in reading. Development In this step, the researcher develops the material design of the media. The designed what the component of the worksheet, what kinds in the worksheet, how to design material from the syllabus and curriculum Implementation. Before the researcher asks the teacher to use research, researchers in the researcher product in class validating by using small Forum Group Discussion (FGD) is the earlier action that research did. In other words, the worksheet would develop by applying this product to the students - the product to the tenth grade at SMA Negeri 4 Palopo. The researcher evaluated the worksheet that has been developed, and the evaluation is done to the 10grade students to find out how the students respond to the worksheet presented by the researcher.

The researchers develop and make a product in according with need and shortcomings of students', and the development of this product is also carried out on based on syllabus and curricula that apply in the school itself. Before the researcher ask the teacher to use research researchers in the researcher product in class validating by using small Forum Group D iscussion (FGD) is the earlier action that research did. In other words, the worksheet would develop by applying this product to the students-the product to the tenth grade at SMA Negeri 4 Palopo. After all the step of analyzed, designed, development, implementation, evaluate had been done, the researchers concluded that students use in SMAN 4 Palopo. The researcher try-out the worksheet to the students. This research with the research by is this research made a worksheet as a media and research by the Siti Munirah made an Article as media. This research used 14 students, and the research by the Nurul Halima used 20 students. And the similarity of this research from previous research is that both want to make a media to facilitate students in learning and to improve students' reading skills.

\section{CONCLUSION}

A worksheet that is suitable for Palopo 10th grade students is a worksheet that matches the worksheet class that matches the needs, disadvantages, of the students, and in accordance with the syllabus and curriculum that applies and is used in the school. The primary purpose of the research is to develop reading worksheet material for tenth-grade students in an odd semester. This worksheet developed to help students and teachers in the teaching and learning process. This worksheet will help students to understand and improve their reading ability because the worksheet includes many kinds of readings, questions, activities, and games.

Based on the student's need analysis, the researcher concluded that most students' abilities in reading still on the Basic (Lower) level. Besides that, most of the student necessity in learning reading is they need to improve their ability in vocabulary section and comprehend, in the other point of view, students lack in mastering vocabulary, the researcher wants to improve the reading by the read many kinds of text such as recount text, and descriptive text. On the other side, the researcher also concluded that the worksheet that the researcher developed already qualified to 
apply in the class. It is proven by the expert validation, which shows the interval of the score is "Appropriate."

\section{REFERENCES}

Abdullah idi. Pengembangan kurikulum teori dan praktik. 2007. Yogyakarta: Ar Ruzz media.

Bachtiar. 2007. Implementasi Pengembangan Content Curriculum dalam Proses PerencanaanPembelajaran. Google Scholar. Surabaya: Universitas Negeri Surabaya.

Borg and Gall (1983).Educational Research, An Introduction. New York and London. Longman Inc.

Bambang Sutedjo,Pengembangan bahan Salinan bambang sutedjo pengembangan bahan ajar.http:id.Wikipedia.org/wiki/Wikipedia: Hak_cipta,diakses tgl 8 mei 2017 pkl 22.00 wita.Salinan

Danielle S McNamara. 2006. Reading Comprehension Strategy. ( New Year). P. 3

Emzir. 2011. Metodologi Penelitian Pendidikan. Jakarta: Raja GrafindoPersada.

Enever, J. (2014). Primary English teacher education in Europe. ELT Journal, 68(3), 231-242. https://doi.org/10.1093/elt/cct079

Grellet, F.I(Developing Reading Skill, Cambridge University Press 1982

Hasanah, Uswatun. 2015. Penerapan Bahan Ajar Worksheet dalam Mencaapai Ketuntasan Belajar Siswa. Google Scholar. Blitar Indonesia: State Islamic Institute of Tulungagung.

Iksan, M., \& Dirham, D. (2018). The Influence of the Economic Students' Motivations and Language Learning Strategies towards Their English Achievement in STIE Muhammadiyah Palopo. Ethical Lingua: Journal of Language Teaching and Literature, 5(1), 110-121. https://doi.org/10.30605/ethicallingua.v5i1.737

Iksan, M., \& Palangngan, S. T. (2018). PEMBERDAYAAN REMAJA MASJID SEBAGAI FASILITATOR PEMBELAJARAN BAHASA INGGRIS DI DESA LESTARI KECAMATAN TOMONI KABUPATEN LUWU TIMUR. Prosiding, 3(1), Article 1. http://journal.uncp.ac.id/index.php/proceding/article/view/819

Kelly, A.V. (1999). The curriculum: theory and practice (4th Ed.). London, UK: $\quad$ Paul Chapman Publishing Ltd.

Marsudi.2014. Hakekat Kurikulum dan Prinsip-prinsip Pengembangan Kurikulum. Google Scholar. Yogyakarta: PPPPTK Seni dan Budaya.

Metode Penelitian Research and Developing (R\&D) | BelajarBahasadanSastra http:// berbahasabersastra.blogspot. com /2011/10metode-penelitian -research-and. Html

Morris, P., and Adamson, P. (2010). Curriculum, schooling, and society in Hong Kong. Hong Kong, HKSAR:Hong Kong University press.

ShobirinMa'as, Subyantoro and RusilowatiAni.2013. Pengembangan Lembar Kerja Siswa Bahasa Inggris Bermuatan Nilai Pendidikan KaraterKelas V Madrasah Ibtidaiyah Semarang. Google Schoolar. Semarang: Journal of Primary Educational.

Sukirman. 2008. Designing Worksheet of English Academic Word for English Education Department Student at IAIN Palopo. Research Article.Palopo Indonesia: Islamic Institut of Palopo.

Sukirman. 2011. Developing Language Learning Materials for Undergraduate Students. Research Article.Palopo Indonesia: American Scientific. 
Teori, Penelitian dan pengembangan volume 1 nomor 7 Bulanjulitahun 2016 halaman 1224-1228

Wang, S.-K., \& Hsu, H.-Y. (2008). Using ADDIE Model to Design Second Life activities for Online Learners. 2045-2050. https://www.learntechlib.org/primary/p/29946/

Wayan, Santyasa. (2009). Metode Penelitian Pengembangan \& Teori Pengembangan Modul. Makalah Disajikan dalam Pelatihan Bagi Para Guru TK, SD, SMP, SMA, dan SMK Tanggal 12-14 Januari 2009, Di Kecamatan Nusa Penida Kabupaten Klungkung. 